\title{
Erratum
}

\section{Lung (DOI: 10.1007/s00408-003-1048-4), published in vol 182/no 2, pp 101-117, 2004}

Figure 8 in the article "Diminished Lung Compliance and Elevated Surfactant Lipids and Proteins in Nutritionally Obese Young Rats", by L.S. Inselman, A. Chander, and A.R. Spitzer was printed incorrectly. The correct Figure 8 is below:
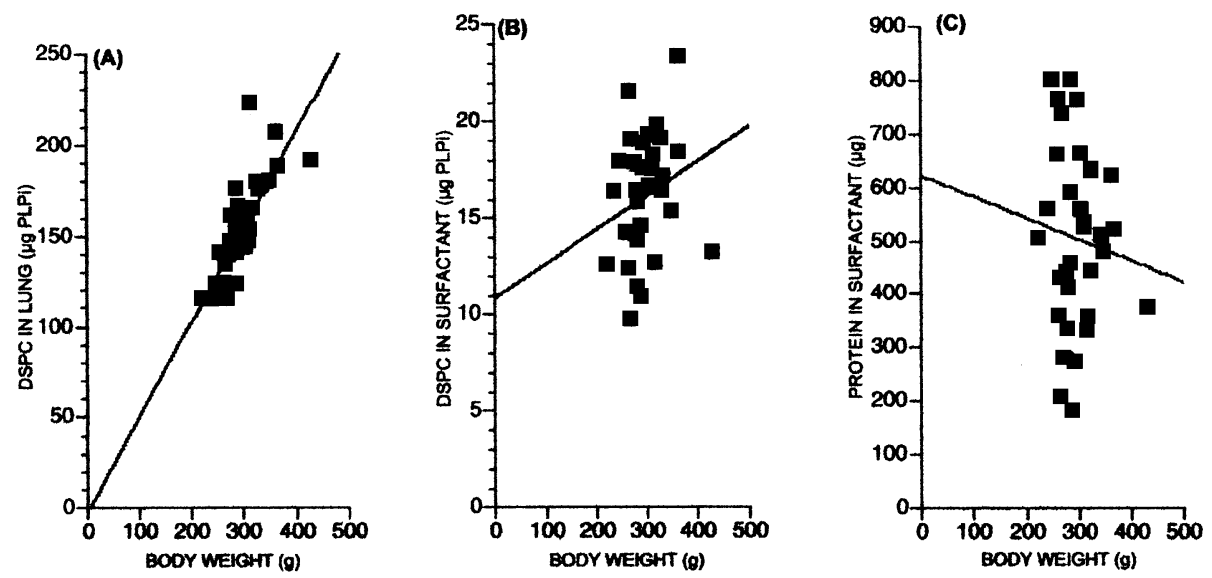

Fig. 8. Linear regression analyses of disaturated phosphatidylcholine (DSPC) content in lung tissue (A) and surfactant (B) and of protein in surfactant (C) as a function of body weight in 8-week-old rats (total 32; control 19; obese, 13). PLPi, phospholipid phosphorus. The regression equations are, for A, $\mathrm{f}(\mathrm{x})=5.238459 \mathrm{E}^{-1 *} \mathrm{x}+-2.318764 \mathrm{E}^{+0}, \mathrm{R}^{2}=0.63$; for $\mathrm{B}, \mathrm{f}(\mathrm{x})=1.782022 \mathrm{E}^{-2} * \mathrm{x}+1.086841 \mathrm{E}^{+1}, \mathrm{R}^{2}$ $=0.05$; for $\mathrm{C}, \mathrm{f}(\mathrm{x})=-4.003834 \mathrm{E}^{-1} * \mathrm{x}+6.230710 \mathrm{E}^{+2}, \mathrm{R}^{2}=0.009$. The $p$ values for correlation are, for $\mathrm{A},<0.001$; for $\mathrm{B},=0.19$; and for $\mathrm{C},=0.60$. There is weak correlation $(\mathrm{r}=0.79)$ of body weight for lung tissue DSPC content. 